\title{
PENYELESAIAN TINDAK PIDANA KONSERVASI OLEH KEPALA BALAI KONSERVASI SUMBER DAYA ALAM YOGYAKARTA
}

\author{
Edi Warsito \\ Email: edi_warsito2007@yahoo.com \\ Mahasiswa Pascasarjana Fakultas Hukum UNS Surakarta \\ Hari Purwadi \\ Email: hpurwadie@gmail.com \\ Dosen Fakultas Hukum UNS Surakarta
}

\begin{abstract}
This article aimed to reveal and analyze the solutions in addressing ownership of protected wildlife carried out by the Yogyakarta Natural Resources Conservation Center (BKSDA). It is a descriptive socio-legal research based on the fifth concept of law, which is law as a manifestation of the symbolic meanings of social perpetrators as seen in the interaction among them. Data were obtained through interview and library research. Analysis technique was qualitative data analysis.Based on the discussion, it can be concluded that the measures conducted by BKSDA Yogyakarta in relation with the issue of protected wildlife ownership is not accordance with the Law No. 5 of 1990 on Conservation.It essential to raise public awareness, particularly those who possess protected wildlife, that the protected wildlife is an integral part of an ecosystem entity. As the follow-up, they will be asked to hand over them to the government and make a statement that they will not repeat their action. By considering the Law No. 5 of 1990 which is imbued with the spirit of the protection, utilization and preservation of biodiversity aimed at the conservation of biodiversity as a single entity of the ecosystem as a buffer for life and survivors of the serious risk of extinction, BKSDA Yogyakarta determines to prioritize the safety of animals. The main purpose of conservation is biological conservation by releasing wildlife into their natural habitat. Measures carried out by BKSDA Yogyakarta are in accordance with one of the objectives of law, namely expediency.
\end{abstract}

Keywords : Wildlife ownership;release of wildlife; releasing

\begin{abstract}
Abstrak
Tujuan artikel ini adalah untuk mengetahui dan menganalisa tentang cara menyelesaikan masalah kepemilikan satwa liar yang dilindungi oleh Balai Konservasi Sumber Daya Alam (BKSDA) D.I Yogyakarta. Penelitian yang dilakukan adalah jenis penelitian hukum sosiologis, bersifat deskriptif dengan menggunakan konsep hukum kelima yaitu hukum sebagai manifestasi maknamakna simbolik para perilaku sosial sebagai tampak dalam interaksi antar mereka. Pengumpulan datanya dilakukan dengan cara wawancara dan studi pustaka. Teknik analisa datanya adalah teknik analisa data kualitatif.Berdasarkan pembahasan dapat disimpulkan bahwa langkah yang ditempuh oleh Balai Konservasi Sumber Daya Alam (BKSDA) D.I Yogyakarta dalam menyelesaikan masalah kepemilikan satwa liar dilindungi undang-undang oleh masyarakat di Yogyakarta adalah tidakmenerapkan hukum, sebagaimana yang diatur dalam undang-undang nomor 5 tahun 1990 tentang konservasi.Masyarakat yang memiliki satwa liar yang dilindungi undang-undang diberikan penyadaran bahwa satwa liar yang dilindungi undang-undang adalah bagian yang tak terpisahkan dari satu kesatuan ekosistem, kemudian diminta untuk menyerahkan
\end{abstract}


satwanya kepada pemerintah dan membuat pernyataan bahwa tidak akan mengulagi lagi perbuatannya.Dengan mempertimbangkan bahwa semangat yang dibawa oleh undang-undang nomor 5 tahun 1990 ini adalah dalam rangka perlindungan, pemanfaatan dan pengawetan keanekaragaman hayati yang bertujuan lestarinya keanekaragaman hayati sebagai satu kesatuan dari ekosistem sebagai penyangga kehidupan dan selamat dari bahaya kepunahan, maka yang lebih diutamakan oleh Balai Konservasi Sumber Daya Alam (BKSDA) D.I Yogyakarta adalah dengan memprioritaskan keselamatan satwanya.Tujuan utama konservasi adalah kelestarian hayati, yang dilakukan dengan melepasliarkan satwa ke habitatnya. Langkah yang diambil oleh Balai Konservasi Sumber Daya Alam (BKSDA) D.I Yogyakarta sudah sesuai dengan salah satu dari tujuan hukum, yaitu kemanfaatan.

Kata kunci: Memiliki satwa liar; menyerahkan satwa; melepasliarkan

\section{A. Pendahuluan}

Indonesia berpredikat sebagai Negara yang berhutan tropis dan mengacu pada prinsipprinsip kelestarian ekologi, sektor kehutanan memiliki kemampuan yang teramat besar bagi terjaminnya kelangsungan hidup umat manusia di dunia. Hutan berfungsi sebagai penyeimbang kelestarian lingkungan secara lintas teritorial, baik lokal, regional maupun global. Hasil kajian para ahli menyebutkan, bahwa fungsi ekologi hutan sebagai daya dukung lingkungan justru memberi peran lebih besar antara 93\%-95\% dibandingkan daya dukung ekonomi dengan menebang hutan secara langsung. Realita ini menyiratkan, bahwa keberadaaan hutan bukan hanya terkait dengan manfaat bagi pemilik atau pengelola hutannya saja tetapi juga bermanfaat bagi masyarakat global.(Untung Iskandar Srihadiono, 205:21)

Indonesia juga terkenal dengan sebutan sebagai Negara megabiodiversity, hal ini karena Indonesia memiliki keanekaragan hayati yang cukup variatif. Keanekaragaman hayati menurut WWF (1989) adalah kekayaan hidup di bumi, jutaan tumbuhan, hewan, dan mikroorganisme, genetika yang dikandungnya dan ekosistem yang dibangunnya menjadi lingkungan hidup.(Richard B.Primack dkk, 1998: hlm: 6).

Keanekaragaman hayati (biological diversity of biodiversity) merupakan istilah umum yang digunakan untuk menggambarkan keragaman kehidupan dan lingkungan yang membentuknya. Keragaman di sini dipahami sebagai gambaran akan luasnya varietas tanaman, binatang dan mikroorganisme keanekaragaman hayati juga mencakup keragaman genetik dalam setiap jenis,kromosome, gene dan DNA merupakan building block yang menentukan keunikan dari masing-masing individu dan jenis (Agus SB Sutito dkk, 2008:1)

Meskipun termasuk negara megadiversitas, saat ini Indonesia terdapat dua kawasan penting (hotspots) keanekaragaman hayati yang sedang terancam, yakni sunda barat dan wallacea, juga kawasan hutan tropis utama, yaitu melanesia termasuk Irian Jaya. Menurut Bird Life, dari 24 kawasan penting untuk burung itu (dengan jumlah tertinggi di dunia), 16 diantaranya menjadi prioritas. (Jatna Supriatna:16)

Indonesia merupakan salah satu Negara yang berada di daerah tropis, mendapat anugerah dari Tuhan berupa hutan yang yang selama ini kita sebut sebagai hutan tropis. Dunia menyebut bahwa hutan yang ada di Indonesia adalah merupakan paru-paru dunia, yang keberadaannya 
sangat penting untuk menjaga stabilitas ekosistem dunia. Hal ini membawa pada sebuah konsekuensi bahwa hutan harus dijaga dan dirawat dengan sebaik-baiknya.

"Indonesia dengan hutan dan ekosistem lainnya, merupakan negara dengan kekayaan dan keanekaragaman hayati pada urutan kedua setelah Brazil, sehingga menempatkan negara tersebut sebagai negara megabiodiversitas dan mega center keanekaragaman hayati dunia. Sebanyak 10\% hutan hujan dunia terletak di wilayah Indonesia, bahkan 50 tahun lalu $82 \%$ wilayah Indonesia tertutup oleh hutan.'(Danang D Cahyadi, Bogor - 22 Maret, 2014, http:// www.greenpeace.org/seasia/id/blog/hutan-indonesia-kekayaan-dan-kompleksitas-mas/

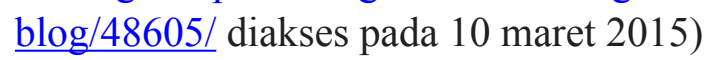

Hutan dan ekosistemnya mempunyai fungsi yang sangat penting bagi kehidupan manusia dan makhluk hidup yang lain. Selain memiliki fungsi yang penting, hutan dengan keanekaragaman hayatinya adalah merupakan kekayaan alam yang tak ternilai harganya, oleh karena itu harus dipertahankan dan dijaga kelestariaannya.

Sumber daya alam dan lingkungan tidak pernah lepas dari berbagai kepentingan seperti kepentingan negara, kepentingan pemilik modal, kepentingan rakyat maupun kepentingan lingkungan itu sendiri. Perebutan kepentingan ini selalu menenpatkan pihak masyarakat sebagai pihak yang dikalahkan. Terbatasnya akses masyarakat dalam pengelolaan sumber daya alam, dan tidak seimbangnya posisi tawar masyarakat adalah contoh klasik dari konflik kepentingan.(I.Gusti Ayu Ketut Rachmi Handayani:72)

Seiring dengan pertambahan penduduk, pertumbuhan ekonomi dan industrialisai, maka tekanan terhadap sumber daya alam menjadi semakin besar. Tingkat kebutuhan dan kepentingan terhadap sumber daya alam juga semakin tinggi. Hal ini dapat dilihat dari berbagai kenyataan betapa pembukaan hutan, kegiatan pertambangan, dan eksploitasi sumber daya alam lainnya dari tahu ke tahun bukannya menurun, akan tetapi semakin besar. Dengan demikian tentunya kawasan-kawasan budidaya maupun kawasan lindung semakin terancam habis, sementara rocovery sumber daya alam yang dapat diperbarui membutuhkan waktu yang lama untuk dapat diperbaiki kembali.(Subarkah:290). Hal tersebut akan berdampak pada berkurangnya atau bahkan hilangnya habitat dari satwa liar apabila eksploitasi tidak terkendali. Tidak heran apabila satwa liar bisa sampai masuk ke pemukiman penduduk, karena tempat tinggalnya dirampas oleh manusia.

Indonesia adalah negara hukum, sebagaimana tercantum dalam pasal 3 Undang-Undang Dasar Tahun 1945 yang menyatakan bahwa "Indonesia adalah negara hukum." Sebagai Negara yang berdasar atas hukum maka konsekuensi logisnya adalah bahwa segala sesuatunya didasarkan pada hukum yang berlaku. Menurut Jimly Ashidiqie dalam konsep Negara Hukum itu, diidealkan bahwa yang harus dijadikan panglima dalam dinamika kehidupan kenegaraan adalah hukum, bukan politik ataupun ekonomi.

Karena itu, jargon yang biasa digunakan dalam bahasa Inggris untuk menyebut prinsip Negara Hukum adalah 'the rule of law, not of man'. Yang disebut pemerintahan pada pokoknya adalah hukum sebagai sistem, bukan orang per orang yang hanya bertindak sebagai 'wayang' dari skenario sistem yang mengaturnya.

Gagasan Negara Hukum itu dibangun dengan mengembangkan perangkat hukum itu sendiri sebagai suatu sistem yang fungsional dan berkeadilan, dikembangkan dengan menata supra struktur dan infra struktur kelembagaan politik, ekonomi dan sosial yang tertib dan 
teratur, serta dibina dengan membangun budaya dan kesadaran hukum yang rasional dan impersonal dalam kehidupan bermasyarakat, berbangsa dan bernegara. Untuk itu, sistem hukum itu perlu dibangun (law making) dan ditegakkan (law enforcing) sebagaimana mestinya, dimulai dengan konstitusi sebagai hukum yang paling tinggi kedudukannya. Untuk menjamin tegaknya konstitusi itu sebagai hukum dasar yang berkedudukan tertinggi (the supreme law of the land), dibentuk pula sebuah Mahkamah Konstitusi yang berfungsi sebagai 'the guardian' dan sekaligus 'the ultimate interpreter of the constitution. ( Jimly Assidhiqie,Sabian Utsman, 2009 : 243)

Keperluan terhadap dasar hukum terhadap konservasi oleh pemerintah telah dipenuhi yaitu dengan membuat sebuah undang-undang, yaitu Undang-undang nomor 5 Tahun 1990 Tentang Konservasi sumber Daya Alam Hayati Dan Ekosistemnya. yang dilakukan melalui kegiatan; perlindungan sistem penyangga kehidupan, pengawetan keanekaragaman jenis tumbuhan dan satwa beserta ekosistemnya dan pemanfaatan secara lestari sumber daya alam hayati dan ekosistemnya. Kegiatan inilah yang kemudian disebut sebagai tiga pilar konservasi.

Eksploitasi satwa liar yang dilakukan oleh manusia dalam memenuhi kebutuhannya harus dilakukan dengan cara yang arif dan bijaksana, dengan tata kelola yang baik. Dari literatur dapat diketahui bahwa;

Pola pengelolaan satwa liar telah berkembang dengan pesat yaitu bukan saja untuk keperluan perlindungan tetapi juga pemanfaatan yang lestari. Pemanfaatan satwa liar ini meliputi untuk kegiatan penelitian, pendidikan, pariwisata dan rekreasi, bahkan jika memungkinkan untuk beberapa jenis satwa tertentu dapat dilakukan pemanenan sebagai komoditi ekspor. Program perlindungan, pelestarian dan pemanfaatan satwa liar seperti ini disebut program konservasi. Untuk memenuhi tujuan pemanfaatan yang lestari, perlu dilakukan upaya pengelolaan satwa liar di luar habitat aslinya. Sehingga kegiatan konservasi dapat dibedakan ke dalam konservasi in-situ dan konservasi ex-situ. Disebut konservasi in-situ jika konservasi satwa liar tersebut dilakukan di habitat aslinya, dan konservasi ex-situ jika dilakukan di luar habitat aslinya, termasuk habitat buatan. Pengelola satwa liar berkepentingan dengan pengelolaan habitat, termasuk vegetasi, makanan, air, dan penyakit. Tujuan dari semua pengelolaan satwa liar pada umumnya adalah untuk melakukan pengendalian terhadap kelimpahan dan penyebaran spesies-spesies satwa liar.(Hadi .S Alikodra, 1990: 11)

Pengelolaan satwa liar merupakan pekerjaan yang membutuhkan pemikiran dan strategi yang matang, karena hasil yang akan dicapai adalah untuk kepentinggan jangka panjang. "Pengelolaan satwa liar adalah kegiatan manusia dalam mengatur populasi dan habitatnya, serta interaksi antara keduanya untuk mencapai keadaan yang sesuai dengan tujuan pengelolaan. Pengelolaan satwa liar dapat dipandang sebagai ilmu untuk mengatur satwa liar beserta habitatnya agar diperoleh keadaan populasi yang lestari. Mengingat bahwa untuk mencapai tujuan pengelolaan tersebut diperlukan berbagai strategi, maka pengelolaan satwa liar disamping merupakan ilmu juga merupakan seni. Tujuan pengelolaan satwa liar ditentukan oleh banyak faktor, seperti status kawasan (cagar alam, suaka margasatwa, taman buru, taman wisata, taman nasional, hutan produksi, ataupun lahan milik penduduk), keadaan populasi serta penyebaran satwa liar, dan permasalahannya. Pengelolaan satwa liar di dalam suaka 
margasatwa bertujuan untuk memelihara populasi agar jumlahnya sesuai dengan kemampuan daya dukung kawasannya. Jika populasi melebihi daya dukung kawasannya dapat dilakukan pengurangan populasi, dan sebaliknya jika pulasi satwa liar sangat rendah diusahakan untuk meningkatkan populasinya, baik melalui pengaturan persaingan, pemangsaan, perbaikan habitat, maupun melindunginya dari berbagai gangguan. Pengelolaan satwa liar di taman nasional dan taman wisata bertujuan untuk memberikan fasilitas yang diperlakukan oleh pengunjung agar mereka dapat menikmati pemandangan dari kehidupan satwa liar di alam bebas. Disamping itu tentunya pengelolaan satwa liar seperti di suaka margasatwa dapat pula dilakukan di taman nasional maupun taman wisata. Sedangkan pengelolaan taman buru yang lestari untuk mencapai hasil pungutan yang maksimal dengan memperhatikan aspek kelestarian populasinya. Sehingga sistem pengelolaannya baik terhadap satwa buru maupun habitatnya dilakukan secara intensif. (Hadi .S Alikodra, 1990: 13-14)

Kehidupan manusia tidak bisa dipisahkan dengan alam, dalam sejarah peradabannya manusia sangat tergantung dengan alam. Bahkan pada masa-masa awal peradaban manusi hidup dalam pola berburu di alam. Sampai saat ini dimana peradaban manusia sudah tergolong sebagai manusia yang modern, sifat naluriahnya untuk berburu satwa masih bisa dirasakan sekalipun sudah dalam bentuk yang berbeda sesuai dengan perkembangan jaman. Ini menunjukkan bahwa keberadaan satwa liar bagi manusia mempunyai nilai tersendiri yang tidak akan pernah bisa tergantikan. Nilai pentingnya satwa liar bagi kehidupan manusia bisa dilihat dari beberapa segi yaitu;(Hadi .S Alikodra, 1990: 19-21).

1) Nilai ekonomis

2) Nilai rekreasi dan kegiatan berburu

3) Nilai keindahan

4) Nilai ilmu pengetahuan

Dalam Undang-undang Nomor 5 tahun 1990 tentang konservasi sumber daya alam hayati dan ekosistemnya mengenai pelanggaran dan kejahatan serta sanksi pidananya diatur dalam BAB V tentang Pengawetan Jenis Tumbuhan dan Satwa, dalam Pasal 21 ayat (2) menentukan bahwa "Setiap orang dilarang untuk:"

a. Menangkap, melukai, membunuh, menyimpan, memiliki, memelihara, mengangkut, dan memperniagakan satwa yang dilindungi dalam keadaan hidup;

b. Menyimpan, memiliki, memelihara, mengangkut dan memperniagakan satwa yang dilindungi dalam keadaan mati;

c. Mengeluarkan satwa yang dilindungi dari suatu tempat di Indonesia ketempat lain di dalam atau di luar Indonesia;

d. Memperniagakan, menyimpan atau memiliki kulit, tubuh, atau bagian bagian lain satwa yang dilindungi atau barang-barang yang dibuat dari bagian-bagian tersebut atau mengeluarkannya dari suatu tempat di Indonesia ketempat lain dalam atau di luar Indonesia;

e. Mengambil, merusak, memusnahkan, memperniagakan, menyimpan atau memiliki telur dan atau sarang satwa yang dilindungi;

Terhadap sanksi tindak pidana konservasi diatur dalam BAB XII Pasal 40 Undang-undang nomor 5 Tahun 1990 tentang konservasi sumber daya alam hayati dan ekosistemnya, dalam ketentuan pidana menentukan sebagai berikut: 
Pasal 40 Ayat (2)

Barang siapa dengan sengaja melakukan pelanggaran terhadap ketentuan sebagaimana dimaksud dalam Pasal 21 ayat (1) dan ayat (2) serta Pasal 33 aya(3) dapat dipidana dengan pidana penjara paling lama 5 (lima) tahun dan denda paling banyak Rp.100.000.000,00 (seratus juta rupiah);

Pasal 40 Ayat (4)

Barang siapa karena kelalaiannya melakukan pelanggaran terhadap ketentuan sebagimana dimaksud dalam Pasal 21 ayat (1) dan ayat (2) serta Pasal 33 ayat (3) dipidana dengan pidana kurungan paling lama 1 (satu) tahun dan denda paling banyak Rp.50.000.000,00 (lima puluh juta rupiah);

Perlu diketahui bahwa dalam Pasal 21 ayat 2 tidak membedakan antara orang yang menyimpan, memelihara, memperdagangkan dan Mengambil, merusak, memusnahkan, memperniagakan, menyimpan atau memiliki telur dan atau sarang satwa yang dilindungi untuk sanksi hukuman yang dikenakan kepada pelaku pelanggaran atau kejahatan tersebut. Ketentuan pidana yang diterapkan yaitu ancaman pidana maksimal 5 (lima) tahun dan denda maksimal Rp.100.000.000 (seratus juta rupiah) bagi yang sengaja melakukan pelanggaran. Sedangkan bagi yang karena kelalaiannya melakukan pelanggaran diancam pidana maksimal 1 (satu) tahun dan denda maksimal Rp.50.000.000 (lima puluh juta rupiah) terhadap siapapun warga Negara yang melakukan pemeliharaan, penyimpanan, perdagangan dan perburuan tanpa ijin terhadap tumbuhan dan satwa liar yang dilindungi undang-undang.

Institusi negara yang mengemban amanat Undang-undang nomor 5 Tahun 1990 Tentang Konservasi Sumber Daya Alam Hayati dan Ekosistemnya adalah kementerian kehutanan,yang dilakukan oleh Unit Pelaksana Teknis (UPT) Balai Konservasi Sumber Daya Alam (BKSDA), untuk wilayah Yogyakarta adalah Balai Konservasi Sumber Daya Alam (BKSDA) Yogyakarta.

Berdasarkan Peraturan menteri kehutanan nomor P. 02 /Menhut-II/2007 tentang oganisasi dan tata kerja unit pelaksana teknis konservasi sumber daya alam,dalam, Pasal 1 ayat 1 menyebutkan bahwa Unit Pelaksana Teknis Konservasi Sumber Daya Alam adalah organisasi pelaksanaan tugas teknis dibidang konservasi sumber daya alam hayati dan ekosistemnya yang berada dibawah dan bertanggung jawab kepada Direktur Jenderal Perlindungan Hutan dan Konservasi Alam.

Dalam Peraturan Menteri kehutanan nomor P.02/Menhut-II/2007 Pasal 3 menyebutkan bahwa dalam Pelaksanaan tugas sebagaimana dimaksud pasal 2, Unit Pelaksanaan Teknis konservasi Sumber Daya Alam menyelenggarakan fungsi:

a. Penataan blok, penyusunan rencana kegiatan, pemantauan dan evaluasi pengelolaan kawasan cagar alam, suaka margasatwa, taman wisata alam, dan taman buru, serta konservasi tumbuhan dan satwa liar di dalam dan diluar kawasan konservasil;

b. Pengelolaan kawasan cagar alam, suaka margasatwa, taman wisata alam, dan taman buru, serta konservasi tumbuhan dan satwa liardidalam dan diluar kawasan konservasi;

c. Koordinasi teknis pengelolaan taman hutan raya dan hutan lindung; 
d. Penyidikan, perlindungan dan pengamanan hutan, hasil hutan dan tumbuhan dan satwa liar didalam dan di luar kawasan konservasi;

e. Pengendalian kebakaran hutan;

f. Promosi, informasi konservasi sumber daya alam hayati dan ekosistemnya;

g. Pengembangan bina cinta alam serta penyuluhan konservasi sumber daya alam hayati dan ekosistemnya;

h. Kerja sama pengembangan konservasi sumberdaya alam hayati dan ekosistemnya serta pengembangan kemitraan;

i. Pemberdayaan masyarakat sekitar kawasan konservasi;

j. Pengembangan dan pemanfaatan jasa lingkungan dan pariwisata alam;

k. Pelaksanaan urusan tata usaha dan rumah tangga.

Balai Konservasi Sumber Daya Alam Yogyakarta sebagaimana diatur dalam pasal 3 Peraturan Menteri kehutanan nomor P.02/Menhut-II/2007huruf d memiliki tugas Penyidikan, perlindungan dan pengamanan hutan, hasil hutan dan tumbuhan dan satwa liar didalam dan di luar kawasan konservasi. dalam menyelesaikan masalah konservasi di wilayah hukumnya dilakukan dengan melaksanakan kegiatan operasi perlindungan dan pengamanan bersifat gabungan maupun fungsional terhadap peredaran ilegal satwa liar yang dilindungi. Operasi ini dilakukan baik terhadap orang-orang yang di rumahnya memelihara atau menyimpan tumbuhaan dan satwa liar yang dilindungi, maupun di tempat-tempat umum baik pasar maupun tempat lain yang menunjukkan aktifitas perdagangan tumbuhan dan satwa liar.

Dengan didasarkan pada peraturan perundangan yang berlaku, tentunya dalam melaksanakan kegiatan operasi penertiban peredaran illegal tumbuhan dan satwa liar, maka baik terhadap perniagaan maupun kepemilikan dan penyimpanan tumbuhan dan satwa liar dan atau bagian-bagiannya harus dilakukan penanganan sesuai dengan hukum yang berlaku, yaitu dengan ditangkap pelakunya, disita barang buktinya, dan diproses hukum terhadap perbuatannya.

Penyelesaikan masalah tindak pidana konservasi khususnya terhadap kepemilikan, satwa liar yang dilindungi, yang dilakasanakan oleh Balai Konservasi Sumber Daya Alam Yogyakarta tidak menerapkan sepenuhnya ketentuan pidana sebagaimana ditentukan dalam Pasal 40 ayat (2) dan ayat (4) Undang-undang nomor 5 Tahun 1990 tentang Konservasi sumber Daya Alam Hayati Dan Ekosistemnya, akan tetapi lebih mengutamakan pendekatan sosial daripada pendekatan hukum.

Balai Konservasi Sumber Daya Alam (BKSDA) Yogyakarta dalam melaksanakan operasi perlindungan dan pengamanan terhadap peredaran tumbuhan dan satwa liar tersebut lebih mengutamakan pendekatan dan menumbuhkan kesadaran pada masyarakat untuk tidak memelihara lagi satwa liar yang dilindungi. Sedangkan terhadap masyarakat yang berkeinginan untuk memelihara satwa liar tersebut pemerintah memberikan fasilitasi melalui apa yang disebut dengan penangkaran.

Keberadaan satwa liar dalam kehidupan manusia, baik dari segi manfaat, fungsi ataupun peranannya harus dijaga, dipertahankan dan dilestarikan. "Melindungi satwa liar dari kepunahan bukanlah hal yang menarik bagi masyarakat pada umumnya. Hanya kalangan terbatas saja dari masyarakat yang peduli terhadap penyelamatan satwa liar ini 
yaitu kalangan konservasionis. Hal ini terjadi karena orientasi dari penyelamatan satwa liar ini cenderung mengutamakan untuk kelangsungan hidupnya spesies. Sedangkan masyarakat lebih berorientasi pada kepentingan ekonomi Kalangan konservasionis perlu melihat jauh kedepan untuk;

a. Melihat apa kebutuhan manusia di masa mendatang.

b. Melakukan persiapan pola pemanfaatan satwa liar untuk memenuhi kebutuhan manusia.

c. Mencari bentuk upaya konservasi yang lebih efektif.

Keberhasilan usaha penyelamatan spesies-spesies yang terancam punah akan banyak ditentukan oleh partisipasi masyarakat. Mereka akan dapat membantu spenuhnya jika telah diketahui adanya manfaat yang sangat besar dari spesies yang bersangkutan bagi kelangsungan hidup manusia. Misalnya dapat dibuktikan bahwa bagian tertentu dari tubuh satu jenis satwa liar dapat menyembuhkan penyakit kanker atau AIDS. Dengan kata lain bahwa masyarakat bisa merasakan manfaat langsung dari penyelamatan satwa liar tersebut. (Hadi .S Alikodra, 1990: 279)

Rehabilitasi adalah proses pengembalian hewan-hewan liar dari kehidupan tangkapan ke kehidupan liar dalam lingkungan alami. Hewan-hewan yang bersangkutan mungkin telah dibiakkan dalam tangkapan atau dimasukkan kedalam tangkapan karena mereka sakit, luka, yatim piatu, atau merupakan hewan-hewan peliharaan atau hewan-hewan kebun binatang. Dalam melakukan rehabilitasi ada beberapa faktor yang perlu diperhatikan yaitu;(Hadi .S Alikodra, 1990: 158-163)

1) Sebab-sebab dari penurunan

2) Kesulitan-kesulitan dan biaya

3) Masalah tingkah laku

4) Masalah belajar

5) Faktor manusia

6) Penyakit

Berdasarkan uraian diatas, dalam artikel ini akan dibahas tentangtindakan apakah yang dilakukan oleh kepala balai KSDA Yogyakarta untuk menyelesaikan masalahkepemilikan satwa liar yang dilindungi undang-undang.

\section{B. Metode Penelitian}

Dalam penelitian ini penulis akan menggunakan konsep hukum yang yang kelima, yaitu bahwa hukum adalah makna-makna simbolik para perilaku sosial sebagai tampak dalam interaksi antar mereka. Sebagaimana dikemukakan oleh Setiono, bahwa "Hukum adalah tingkah laku atau aksi-aksi dan interaksi manusia secara aktual dan potensial akan terpola.

Karena setiap perilaku atau aksi itu merupakan suatu realita sosial yang terjadi dalam alam pengalaman indrawi dan empiris, maka setiap penelitian yang mendasarkan atau mengkonsepkan hukum sebagai tingkah laku atau perilaku dan aksi ini dapat disebut sebagai penelitian sosial (hukum).(Setiono, 2010 : 22.) 


\section{Hasil Penelitian Dan Pembahasan}

Dari penelitian yang telah dilaksanakan pada Balai Konservasi Sumber Daya Alam (BKSDA) Yogyakarta didapatkan hasil sebagai berikut;

Dalam kurun waktu tahun 2012 sampai dengan tahun 2016, dapat mengevakuasi satwa liar dari masyarakat sebanyak 213 satwa hidup maupun opset atau bagian-bagiannya. Data lebih rinci untuk jenis dan jumlah per tahun disajikan dalam tabel berikut;

Data statistik Balai Konservasi Sumber Daya Alam (BKSDA) Yogyakarta tahun 2012

\begin{tabular}{|l|l|l|c|}
\hline \multicolumn{1}{|c|}{ Bulan } & \multicolumn{1}{|c|}{ Nama Jenis } & \multicolumn{1}{c|}{ Kondisi } & Jumlah \\
\hline Maret & Buaya muara & Opset & 2 \\
\hline \multirow{4}{*}{ April } & Elang bondol & Hidup & 1 \\
\cline { 2 - 4 } & Kakatua kecil jambul kuning & Hidup & 2 \\
\cline { 2 - 4 } & Buaya muara & Hidup & 1 \\
\cline { 2 - 4 } & Elang ular bido & Hidup & 1 \\
\hline \multirow{2}{*}{ JUMLAH } & & 7 \\
\hline
\end{tabular}

Data statistik Balai Konservasi Sumber Daya Alam (BKSDA) Yogyakarta tahun 2013

\begin{tabular}{|c|c|c|c|}
\hline Bulan & Nama Jenis & Kondisi & Jumlah \\
\hline Januari & Elang ular bido & Hidup & 1 \\
\hline \multirow{5}{*}{ Februari } & Elang ular bido & \multirow{5}{*}{ Hidup } & 2 \\
\hline & Elang brontok & & 2 \\
\hline & Elang laut & & 1 \\
\hline & Alap-alap tikus & & 1 \\
\hline & Nori merah kepala hitam & & 1 \\
\hline \multirow{15}{*}{ April } & Elang hitam & \multirow{2}{*}{ Hidup } & 1 \\
\hline & Elang Bido & & 1 \\
\hline & Elang brontok & - & 1 \\
\hline & Kakatua jambul kuning & \multirow{12}{*}{ Hidup } & 1 \\
\hline & Merak Hijau & & 7 \\
\hline & Elang jawa & & 1 \\
\hline & Elang hitam & & 1 \\
\hline & Elang brontok & & 3 \\
\hline & Elang bondol & & 1 \\
\hline & Elang laut & & 1 \\
\hline & Alap-alap tikus & & 1 \\
\hline & Alap-alap jambul & & 1 \\
\hline & Alap-alap kawah & & 1 \\
\hline & Merak hijau & & 2 \\
\hline & Elang brontok & & 2 \\
\hline
\end{tabular}




\begin{tabular}{|c|c|c|c|}
\hline Bulan & Nama Jenis & Kondisi & Jumlah \\
\hline & Elang hitam & \multirow{5}{*}{ Hidup } & 1 \\
\hline & Elang brontok & & 1 \\
\hline & Kijang & & 2 \\
\hline & Elang ular bido & & 1 \\
\hline & Sendanglawe & & 1 \\
\hline \multirow{2}{*}{ Mei } & Kakatua jambul kuning & \multirow{2}{*}{ Hidup } & 4 \\
\hline & Rusa timor & & 1 \\
\hline \multirow{2}{*}{ Juni } & Owa kalaweit & \multirow{2}{*}{ Hidup } & 1 \\
\hline & Kakatua jambul kuning & & 1 \\
\hline \multirow{7}{*}{ Juli } & Elang brontok & \multirow{7}{*}{ Hidup } & 4 \\
\hline & Nori bayan & & 2 \\
\hline & Kakatua jambul kuning & & 3 \\
\hline & Merak hijau & & 2 \\
\hline & Nori merah kepala hitam & & 1 \\
\hline & Macan tutul & & 3 \\
\hline & Kucing hutan & & 2 \\
\hline Agustus & Kakatua jambul kuning & Hidup & 1 \\
\hline \multirow{3}{*}{ September } & Merak hijau & \multirow{3}{*}{ Hidup } & 1 \\
\hline & Elang brontok & & 1 \\
\hline & Kakatua goffini & & 2 \\
\hline \multirow{3}{*}{ Oktober } & Kakatua jambul kuning & \multirow{3}{*}{ Hidup } & 5 \\
\hline & Elang perut karat & & 1 \\
\hline & Ular phyton & & 1 \\
\hline \multirow{7}{*}{ November } & Siamang & \multirow{7}{*}{ Hidup } & 1 \\
\hline & Kakatua jambul kuning & & 2 \\
\hline & Nori merah kepala hitam & & 2 \\
\hline & Elang brontok & & 2 \\
\hline & Anakan elang & & 2 \\
\hline & Alap-alap tikus & & 1 \\
\hline & Elang laut & & 1 \\
\hline \multicolumn{3}{|l|}{ JUMLAH } & 86 \\
\hline
\end{tabular}

Data statistik Balai Konservasi Sumber Daya Alam (BKSDA) Yogyakarta tahun 2014

\begin{tabular}{|c|l|l|c|}
\hline Bulan & \multicolumn{1}{|c|}{ Nama Jenis } & Kondisi & Jumlah \\
\hline \multirow{4}{*}{ Januari } & Buaya muara & & 1 \\
\cline { 2 - 2 } & Kukang & & 1 \\
\cline { 2 - 2 } \cline { 4 - 4 } & Owa Kalimantan & 2 \\
\hline
\end{tabular}


Edi Warsito. Penyelesaian Tindak Pidana Konservasi Oleh Kepala Balai Konservasi Sumber Daya Alam...

\begin{tabular}{|c|c|c|c|}
\hline Bulan & Nama Jenis & Kondisi & Jumlah \\
\hline \multirow{2}{*}{ Februari } & Musang garis & \multirow{2}{*}{ Hidup } & 1 \\
\hline & Kucing hutan & & 1 \\
\hline \multirow{11}{*}{ Maret } & Kuskus & \multirow{11}{*}{ Hidup } & 1 \\
\hline & Lutung & & 1 \\
\hline & Cendrawasih & & 1 \\
\hline & Landak & & 1 \\
\hline & Buaya muara & & 1 \\
\hline & Elang brontok fase gelap & & 2 \\
\hline & Kucing hutan & & 2 \\
\hline & Beluk jampuk & & 1 \\
\hline & Kokok beluk & & 2 \\
\hline & Kukang & & 1 \\
\hline & Musang pandan & & 6 \\
\hline \multirow{7}{*}{ April } & Kijang & \multirow{7}{*}{ Hidup } & 1 \\
\hline & Owa Kalimantan & & 1 \\
\hline & Rusa timor & & 1 \\
\hline & Elang brontok fase gelap & & 2 \\
\hline & Elang bondol & & 1 \\
\hline & Kakatua tanimbar & & 1 \\
\hline & Kakatua jambul kuning & & 1 \\
\hline Mei & Kancil & Hidup & 4 \\
\hline Juni & Elang laut perut putih & Hidup & 1 \\
\hline \multirow{2}{*}{ Juli } & Elang bondol & \multirow{2}{*}{ Hidup } & 1 \\
\hline & Buaya muara & & 1 \\
\hline Agustus & Monyet ekor panjang & Hidup & 1 \\
\hline \multirow{2}{*}{ September } & Elang bondol & \multirow{2}{*}{ Hidup } & 1 \\
\hline & Elang sikep madu & & 1 \\
\hline \multirow{2}{*}{ Oktober } & Kakatua jambul kuning & \multirow{2}{*}{ Hidup } & 2 \\
\hline & Kucing Hutan & & 1 \\
\hline \multicolumn{3}{|l|}{ JUMLAH } & 46 \\
\hline
\end{tabular}

Data statistik Balai Konservasi Sumber Daya Alam (BKSDA) Yogyakarta tahun 2015

\begin{tabular}{|l|l|c|c|}
\hline Bulan & \multicolumn{1}{|c|}{ Nama Jenis } & Kondisi & Jumlah \\
\hline \multirow{2}{*}{ Januari } & Tanduk Rusa & & 1 \\
\hline \multirow{3}{*}{ Maret } & Owa Kalimantan & \multirow{3}{*}{ Hidup } & 1 \\
\cline { 2 - 2 } & Elang Brontok & & 1 \\
\cline { 2 - 2 } & Merak Hijau & & \\
\hline April & - & & \\
\hline
\end{tabular}




\begin{tabular}{|c|c|c|c|}
\hline Bulan & Nama Jenis & Kondisi & Jumlah \\
\hline \multirow{4}{*}{ Mei } & Nori merah kepala hitam & \multirow{4}{*}{ Hidup } & 1 \\
\hline & Kakatua putih & & 1 \\
\hline & Kancil & & 2 \\
\hline & Kakatua jambul kuning & & 1 \\
\hline \multirow{5}{*}{ Juni } & Cekakak jawa & \multirow{5}{*}{ Hidup } & 2 \\
\hline & Elang ular bido & & 2 \\
\hline & Merak hijau & & 1 \\
\hline & Kakatua jambul kuning & & 1 \\
\hline & Elang brontok & & 1 \\
\hline Juli & - & & \\
\hline \multirow{6}{*}{ Agustus } & Kakatua jambul kuning & \multirow{6}{*}{ Hidup } & 2 \\
\hline & Nori merah kepala hitam & & 1 \\
\hline & Kucing hutan & & 4 \\
\hline & Kukang & & 1 \\
\hline & Elang jawa & & 2 \\
\hline & Kangkerang & & 1 \\
\hline \multirow{4}{*}{ September } & Merak hijau & \multirow{4}{*}{ Hidup } & 1 \\
\hline & Kakatua jambul kuning & & 1 \\
\hline & Jalak putih & & 2 \\
\hline & Kukang & & 1 \\
\hline \multirow{2}{*}{ Oktober } & Elang brontok & \multirow{2}{*}{ Hidup } & 1 \\
\hline & Kakatua jambul kuning & & 1 \\
\hline Desember & Elang ular bido & Hidup & 2 \\
\hline \multicolumn{3}{|l|}{ JUMLAH } & 36 \\
\hline
\end{tabular}

Data statistik Balai Konservasi Sumber Daya Alam (BKSDA) Yogyakarta tahun 2016

\begin{tabular}{|c|c|c|c|}
\hline Bulan & Nama Jenis & Kondisi & Jumlah \\
\hline \multirow{2}{*}{ Maret } & Kakatua putih jambul kuning & Hidup & 1 \\
\hline & Penyu sisik & Opset & 1 \\
\hline \multirow{8}{*}{ April } & Binturong & \multirow{7}{*}{ Hidup } & 1 \\
\hline & Beruang madu & & 1 \\
\hline & Lutung jawa & & 1 \\
\hline & Elang brontok fase gelap & & 1 \\
\hline & Anakan merak & & 13 \\
\hline & Sanca bodo & & 3 \\
\hline & Elang bido & & 1 \\
\hline & Cendera wasih & Opset & 2 \\
\hline
\end{tabular}




\begin{tabular}{|l|l|l|c|}
\hline \multicolumn{1}{|c|}{ Bulan } & \multicolumn{1}{|c|}{ Nama Jenis } & Kondisi & Jumlah \\
\hline \multirow{2}{*}{ Mei } & $\begin{array}{l}\text { Kakatua putih besar jambul } \\
\text { kuning }\end{array}$ & Hidup & 1 \\
\hline \multirow{2}{*}{ Juni } & Merak hijau & Hidup & 1 \\
\cline { 2 - 2 } & Elang bondol & Hidup & 1 \\
\hline Juli & Kukang jawa & \multirow{2}{*}{ Hidup } & 1 \\
\hline \multirow{2}{*}{ Agustus } & Merak hijau & & 2 \\
\cline { 2 - 4 } & Siamang & Hidup & 2 \\
\hline September & Merak hijau & \multirow{2}{*}{ Hidup } & 1 \\
\hline \multirow{2}{*}{ Oktober } & Kakatua seram & & 1 \\
\cline { 2 - 2 } & Merak hijau & 36 \\
\hline JUMLAH & \multicolumn{2}{|l}{} \\
\hline
\end{tabular}

Tindakan dan langkah-langkah yang dilakukan oleh Balai Konservasi Sumber Daya Alam (BKSDA) Yogyakarta untuk menyelesaikan permasalahan tindak pidana kepemilikan satwa liar yang dilindungi udang-undang oleh masyarakat tidak diselesaikan dengan menerapkan ketentuan sebagaimana diatur dalam undang-undang nomor 5 tahun 1990 tentang konservasi pasal 21 ayat (2) jo pasal 40 ayat (2) dan ayat (4).

Penyelesaian masalah kepemilikan satwa liar dilindungi undang-undang di wilayah Yogyakarta oleh Balai Konservasi Sumber Daya Alam (BKSDA) Yogyakarta dilakukan dengan menggunakan metode pendekatan sosial, yaitu masyarakat yang memiliki satwa liar dilindungi diberikan sosialisasi dan penyadaran terhadap pentingnya konservasi sumber daya alam hayati dan ekosistemnya, kemudian diminta untuk menyerahkan satwa liar dilindungi yang dimiliki kepada Balai Konservasi Sumber Daya Alam (BKSDA) Yogyakarta.

Mengapa penyelesaian masalah kepemilikan satwa liar yang dilindungi undang-undang di wilayah Yogyakarta tidak bisa dilakukan dengan menerapkan Undang-undang nomor 5 tahun 1990 tentang Konservasi Sumber daya Alam Hayati dan Ekosistemnya secara murni dan konsekuen? Hal ini disebabkan oleh beberapa faktor, antara lain adalah faktor ekonomi, sosial dan budaya masyarakat Yogyakarta.

Di lingkungan masyarakat Yogyakarta yang masih bersifat agraris, pola hidup masyarakatnya sangat dipengaruhi oleh adat istiadat dan kebudayaan alam pedesaan yang masih kuat. Dalam kehidupannya sehari-hari masyarakat agraris seperti ini sangat dipengaruhi oleh alam pikiran yang masih kental dengan nilai-nilai mitos, cerita-cerita rakyat (legenda).

Adat kebiasaan yang masih kuat dalam kehidupan masyarakat agraris tersebut akan sangat berpengaruh terhadap kehidupan sahari-hari, baik itu dalam sistem ekonomi maupun kehidupan sosial budayanya. Nilai-nilai yang telah diajarkan telah menyatu dalam sistem kehidupan sehari-hari, sehingga membentuk sikap hidup dan perilaku yang mengurat mengakar sehingga tidak mudah untuk bisa mengubahnya.

Kebiasaan yang masih sering terjadi dalam lingkungan kehidupan masyarakat pedesaan adalah kegiatan memelihara satwa. Memelihara satwa bagi masyarakat Indonesia, khususnya Yogyakarta adalah merupakan adat kebiasaan yang sudah turun temurun yang merupakan 
wujud dari kecintaan ataukelangenan terhadap satwa liar, yang untuk masyarakat kelas tertentu bisa menambah nilai status sosial. Ini tidak bisa dilepaskan dari nilai-nilai yang diajarkan oleh leluhur yang sudah menjadi tradisi.

"Di dalam kehidupan masyarakat jawa ada tradisi bahwa seseorang itu telah disebut menjadi “Orang" maksudnya sudah sukses dalam kehidupan, baik secara status sosial maupun ekonomi. Secara simbolik, menjadi "Orang” berarti sudah memiliki 5 (lima) hal yaitu; wismo, garwo, kukilo, turonggo, curigo"(Sutamat Arywibowo, 2010, 209: 9 jmb-lipi.or.id>article, download hari Senin 11 September 2017 pukul 10.47 WIB)

yang kurang lebih mengandung maksud bahwa pria jawa itu sudah sempurna kalau telah memiliki wismo $=$ rumah, garwo $=$ istri, turonggo $=$ kuda $=$ hewan kendaraan, (alat transportasi), kukilo $=$ hewan piaraan, kelangenan,(hiburan/kesenangan), dan curigo $=$ keris $=$ senjata (mata pencaharian).

Oleh karena itulah maka dalam rangka untuk bisa membentuk sikap pola hidup pada masyarakat yang sadar untuk tidak memiliki dan memelihara satwa liar yang dilindungi undang-undang diperlukan suatu proses penyadaran, yang dilakukan dengan sosialisasi dan menbentuk kader-kader konservasi di segala lapisan masyarakat.

Selain faktor budaya masyarakat, yang menjadi sebab tidak bisa dilaksanakannya Undang-undang nomor 5 tahun 1990 tentang Konservasi Sumber daya Alam Hayati dan Ekosistemnya secara murni dan konsekuen adalah adanya kewenangan berupa diskresi dari pejabat Unit Pelaksana Teknis (UPT) Kementerian Lingkungan Hidup dan Kehutanan.

Dengan kewenangan diskresinya tersebut pejabat dari Unit Pelaksana Teknis (UPT) Kementerian Lingkungan Hidup dan Kehutanan dapat mengambil langkah-langkah apa yang akan dilakukan atau tidak dilakukan dalam menyelesaikan masalah kepemilikan dan pemeliharaan satwa liar yang dilindungi undang-undang dengan pertimbangan-pertimbangan tertentu.

Faktor lainnya adalah teknis penanganan satwa liar yang dilindungi undang-undang pasca dievakuasi dari masyarakat. Perlakuan terhadap satwa liar yang sudah dimiliki dan dipelihara manusia dalam jangka waktu yang lama akan memiliki tingkat kesulitan yang lebih tinggi apabila dibandingkan dengan satwa yang baru di dapat dari alam. Oleh karena itu maka diperlukan teknis tertentu untuk bisa menjaga, melindungi, mempertahankan dalam kondisi sebagaimana mestinya, mengingat satwa liar memiliki perilaku yang berbeda-beda untuk setiap jenisnya. Satwa adalah makhluk hidup, bukan benda mati yang bisa dengan mudah untuk diambil dan disimpan.

Karena tujuan konservasi adalah untuk keselamatan, perlindungan dan pelestarian, maka dari itu keselamatan satwa dan kelangsungan hidupnya lebih diutamakan. Animal welfare menjadi faktor yang sangat penting dalam melakukan penanganan terhadap satwa liar yang dilindungi undang-undang tersebut. Segala tindakan yang diambil untuk handling satwa harus dilakukan dengan teliti oleh orang yang berkompeten yaitu keeper satwa dan dokter hewan supaya dapat meminimalisir terjadinya resiko kematian dari satwa liar tersebut.

Karena satwa liar yang sudah lama dimiliki dan dipelihara oleh manusia dan mendapat perlakuan-perlakukan seperti binatang domestifikasi, menyebabkan satwa tersebut memiliki ikatan emosional dan ketergantungan dengan yang memiliki. Dengan adanya hubungan 
emosional dan ketergantungan yang tinggi pada manusia tersebut, maka apabila satwa tersebut dipisahkan dengan pemiliknya menyebabkan satwa liar tersebut stres dan sakit. Kemungkinan terburuk satwa liar tersebut apabila dipisahkan dari pemiliknya maka akan mudah stres, sakit dan akhirnya satwa tersebut mati.

Faktor penting selain faktor budaya masyarakat, kewenangan diskresi dan teknis handling satwa, sebagaimana dijelaskan sebelumnya, adalah adanya kesiapan dari pemerintah untuk memenuhi kebutuhan sarana prasana infrastruktur, tenaga dan anggaran untuk seluruh satwa pasca dievakuasi dari masyarakat. Kebutuhan tenaga dokter hewan, keeper satwa, kandang evakuasi, kandang rehabilitasi, kandang habituasi, biaya perawatan satwa baik medis maupun non medis, tembak bius, memerlukan anggaran biaya dan tenaga yang sangat besar. Sarana dan prasarana yang dimiliki Balai KSDA Yogyakarta masih kurang memadai, dokter hewan 1 (orang) kandang rehabilitasi hanya terdapat di Stasiun Flora Fauna (SFF) Bunder hanya terbatas untuk jenis aves (burung), tidak ada tembak bius, kandang kubah habituasi dan lokasi habituasi. Dengan keterbatasan sarana dan prasarana yang ada, maka evakuasi atau pengambilan satwa yang dipelihara oleh masyarakat tidak bisa dilaksanakan secara optimal. Dari beberapa faktor tersebut diatas apabila ditinjau dari sudut pandang teori penegakan hukum dari Soerjono Soekanto, disebutkan bahwa untuk melihat apakah hukum itu ditegakkan atau tidak, paling sedikit hukum itu harus meliputi paling sedikit 4 faktor yaitu:(Hartiwiningsih:18)

1) Peraturan hukum itu sendiri

2) Aparat yang menegakkan ukum

3) Masyarakat yang terkena peraturan hukum

4) Sarana dan prasarana yang mendukung ditegakkannya peraturan tersebut

\section{Simpulan}

Dari hasil penelitian dan pembahasan terhadap permasalahan yang diangkat, penulis mengambil kesimpulan sebagai berikut:

Tindakan yang dilakukan oleh Kepala Balai Konservasi Sumber Daya Alam (BKSDA) Yogyakarta adalah dengan pembinaan, sosialisasi dan penyadartahuan kepada masyarakat tentang arti dan pentingnya konservasi guna melahirkan kader-kader konservasidan memberikan fasilitasi terhadap masyarakat yang mempunyai komitmen yang tinggi terhadap konservasi satwa liar untuk diarahkan kepada kegiatan penangkaran atau lembaga konservasi.

\section{E. Saran}

Untuk mengatasi permasalahan dalam proses penyelesaian masalahkepemilikan satwa liar yang dilindungi undang-undang yang dilakukan oleh masyarakat, disarankansebagai berikut:

Kepala Balai Konservasi Sumber Daya Alam (BKSDA) Yogyakarta membuat bank data tentang kepemilikan satwa liar yang dilindungi undang-undang, melakukan pembinaan dan sosialisasi tentang pentingnya konservasi terhadap masyarakat yang dilakukan dengan intensif, terprogram dan konsisten, serta harus dapat memberikan solusi yang cepat dan aplikatif terhadap permasalahan yang terjadi di masyarakat, membuat rencana, program 
yang jelas dan transparan dengan landasan peraturan perundangan yang memadai, sehingga tidak menimbulkan permasalahan di kemudian hari.

\section{F. Daftar Pustaka}

\section{Buku}

Jimly Assidhiqie, Sabian Utsman. 2009. Dasar-dasar Sosiologi hukum, makna dialog antara hukum dan Masyarakat. Yogyakarta: Pustaka Pelajar

Setiono, 2010.Pemahaman Terhadap Metodologi Penelitian hukum, Surakarta.

Salim HS,. dan Erlies Septiana Nurbani. 2013. Penerapan teori hukum pada penelitian tesis dan desertasi. Jakarta: PT. Raja Grafindo Persada.

Hadi. S Alikodra, 1990,Pengelolaan Satwa Liar Jilid 1, Departemen Pendidikan dan Kebudayaan Dirjen Dikti Pusat antar Universitas ilmu hayat IPB

Jatna Supriatna. 2008. Melestarikan Alam Indonesia. Jakarta: Yayasan Obor Indonesia.

\section{Internet}

Sutamat Arywibowo, 2010, 209: 9 jmb-lipi.or.id>article, download hari Senin 11 September 2017 pukul 10.47 WIB

http://www.greenpeace.org/seasia/id/blog/hutan-indonesia-kekayaan-dan-kompleksitasmas/blog/48605/ oleh Danang D Cahyadi, Bogor - 22 Maret, 2014, diakses pada 10 maret 2015

\section{Jurnal}

Subarkah.2015 "Implementasi Hukum Progresif Dalam Pembangunan Berkelanjutan Ekologis". Yudisial. Vol.8 No.3.

I.Gusti Ayu Ketut Rachmi Handayani.2006. "Krisis Air,Illegal Loging dan Penegakan Hukum Lingkungan Hidup di Indonesia”.yustisia. Edisi nomor 69.

Hartiwiningsih.2008. “Kebijakan Hukum Pidana Dalam Menanggulangi Masalah Tindak Pidana Lingkungan Hidup di Indonesia“ Yustisia edisi Nomor 74. 